\title{
Changeover of a Child into a Serial Killer Victimization of the Voiceless
}

\author{
Ramya S, Roshanara M. S. \\ Department of English, Sri Krishna Adithya College of Arts and Science, Coimbatore, India
}

\begin{abstract}
Trauma can be encountered almost in all walks of life. When a person is denied of something or illtreated by someone in the childhood the anger of the child is shown on someone. Mostly, on the ones that are weaker especially animals. In future this ill-treated child becomes a serial killer who incepts his off-centered mien by torturing and killing animals. Animal abuse takes place in all parts of the world, where animals are tortured cruelly and put to death for no reason. This paper tries to analyze the reasons behind a person who intentionally tortures animals.
\end{abstract}

Keywords-Intentional Animal Torture and Cruelty, Traumatic Childhood, Victimization of Voiceless, Serial Killing of Animals.

\section{INTRODUCTION}

Animal cruelty is often seen as a link between family and social violence. People who mistreat animals show the same behavior towards vulnerable people around them. IATC is done as the matter of power, as a result of childhood trauma that turns the individual into a future serial killer. On consideration of human and animal relationship, this research focuses on the people who harm someone they perceive weaker, especially animals. Many serial killers feel a sense of rejection from their parents or someone they love. There is either a perceived rejection or a real rejection. Rather than going after the person who rejected them, they will start with someone they perceive weaker, and often that is an animal. It is a matter of power. Childhood cruelty towards animals is the first warning sign of later delinquency, violence and criminal behavior. Curiosity or exploration may also be a reason for a young child to abuse animal. The animal is injured or killed in the process of being examined by a young child. Peer pressure is also a reason for torturing animals. Peers may encourage the individual to abuse an animal or require it as a part of an initiate rite. Mood enhancement, abusing animal is thought to relieve boredom or depression. Violence on stray animals or pets is done before engaging in violent acts against other people. There is a powerful link between bestiality like sexual relationship between human and an animal and later it turns to interpersonal violence. People who commit bestiality at a young age are significantly more like to commit interpersonal violence. The trauma undergone by the individual turns him to a future serial killer, he starts killing non-human animals that gradually turns towards the society. This research also focuses on the negative impacts of Speciesism and brings in animalographies as the solution.

\subsection{IATC}

Intentional Animal Torture and Cruelty is encountered in all the nooks and corners of the world. Humans tend to harm animals for the sake of pleasure. Instead of educating the young minds in a zoo, they teach the children to keep the animals in bars and to torture them.

Animals are used in experimental laboratories to test medicines. Medicines are not tested upon humans because they value the life of humans more than that of animals. Many animals are taken to slaughter houses. If an animal is pregnant and gives birth, the milk of that animal is taken for the purpose of commodity; people do not notice the hungry calf behind it. If the calf is male and is not used for any breeding purpose then they are castrated without pain killers. The penis of the male is beaten with a hammer and is taken to slaughter houses. If a practice causes serious harms, then that practice is morally wrong. Therefore, the practice of raising and killing animals for food is morally wrong. The sufferings of those innocents are left uncared by the humans. They are seen as four legged creatures and not as lively beings. Animal torture is done for various reasons. It is done for the purpose of entertainment (eg. movie Cannibal Holocaust).

Many animals are tortured and killed; in the circus animals are tortured in the name of entertainment. Dog fighting involves crimes such as drugs, guns, illegal gambling, pet theft, murder, and gang violence. Animals are also killed for the ritual practice in many parts of the world. Animals are tortured cruelly in industrial agriculture process, where to increase the production they milk the cows to a very crucial extent which results in the 
death of an animal. The fur of the animals is taken for the purpose of clothing, in simple terms someone is made naked and put nearly to death to make us pretty and beautiful. To enjoy the tasty food many animals are taken to slaughter houses every day. During the Stone Age people fed upon the raw flesh of the animals, they are called as barbaric or uncivilized beings. Now one call himself as civilized and well educated but still indulges in barbaric acts. In name of civilization the humanity in the world starts fading. Humans consider that the world is only for human beings and not for the five sense beings. The rate of killing animals increases day by day.

Animal cruelty is done in various ways naming it as the process of human living. Animal abuse is a worldwide problem that causes incalculable degree of animal suffering. Number of definitions for animal abuse had been proposed, although abuse is an intentional act that causes harm to an individual or an animal. It is a socially unacceptable behaviour that intentionally causes unnecessary pain, suffering, distress or death to an animal. This includes, kicking animals and throwing them against the wall, across a room, downstairs, out of a window, hitting with broom, hammer, burning, stabbing, incisional woundsand sexual abuse, administration of drugs or poison, and swinging by the tail. In literature these injuries are referred as non-accidental injuries (NAI). According to Tallichet, a well known businessman and owner of many military aircrafts shooting, hitting and kicking animals are the most common forms of abuse. Sex with animals, bestiality is also a type of animal abuse.

\subsection{Animal Abuse and Interpersonal Violence}

There is a visible link between animal abuse and interpersonal violence. Animal cruelty can be often seen as the link between family and social violence. There are significant evidences to prove that people, who mistreat and abuse animals show the same behaviour toward vulnerable people around them, such as children or older adults and some men abusers abuse women, they go for the ones who they consider to be weaker. The other aspect focuses on animal abuse as risk factor for other criminal activities, such as human trafficking, drugs, and dog fighting etc. Many convicted murderers had a history of animal abuse.

Animal cruelty is linked directly or indirectly with all type of violent crimes and even with most non-violent crimes. Human beings would benefit enormously if animal cruelty were taken seriously. Many human lives would be saved and much human suffering would be prevented. Violent individuals are made and not born. Children are born with a love for animals, but the environment in which they live plays a major role in determining a child's pro-social or antisocial personality and behaviour.Children are born with a love and fascination for animals. Babies are comforted by the teddy bears. When they get little older, they give a hug for a kitten, rabbit, or dog they keep the animals next to their parents. Yet a few years later, some children turn into killers. This is because of the child abuse, neglect, abandonment, and witnessing of domestic violence that creates violent individuals. Enuresis, arson, and animal cruelty in children are early identifying factors related to future violence. Early intervention may be effective in changing the pathological path taken by the child. The majority of juvenile crime offenders and school shooters were involved in animal cruelty. Most violent crimes are committed by young people under the age of thirty.

Majority of prison inmates involve in animal cruelty at some part of time in their early lives. Serial killers are closely linked with animal cruelty, so much so that it is exceedingly rare to find one who did not begin his or her career with animal abuse. Domestic violence, like child abuse, spouse battering and elder abuse is closely associated with animal cruelty. Perpetrators use animal cruelty to control women and children in abusive situations. Battered women often remain in abusive situations out of fear for their pet. Animal cruelty is more likely traced in domestic violent households than in non domestic violent households. Stopping domestic violence is a key to reduce a violent culture. Nearly all violent criminals and violent psychiatric patients were abused as children, and nearly all started committing animal cruelty at a very early age.There are many reasons behind intentional animal torture and cruelty. A person tortures animal because he considers them as weaker organisms and think him to be strong and superior. When the life histories of serial killers are taken into account, they think them to be superior beings than anyone. To register the superiority, they kill and torture the non human animals. If a person has some vengeance with his neighbour he tortures the pet of his neighbour. This act of torturing the animals makes them to feed the feeling of superiority. They consider animals as weaker beings than humans.

Terror Management Theory states that, death anxiety drive people to adopt world views that protect their sense of self esteem, worthiness, sustainability and allow them to believe that they play an important in a meaningful world. The theory posits that humans use self-esteem as a buffer against fear of death. Human survival instincts, and need to reinforce in the face of death, often result in displays of prejudice, or the belief that the group with which one identifies is superior to other groups. Here the other groups represent the non human animals. According to this theory, 
individuals of this trait to think themselves immortal, in simple terms humans will have a behaviour or thought that every human beings are born in this world and they are going to die and not immortal like god. This thought of the human beings make tem to attain their self-esteem before their death. The self-esteem of these people is to register their superiority in this world. On this process to register their superiority they choose some beings which are considered by them to be weaker. Probably they choose animals to show their superiority. They just enjoy the cruelty done to those little innocent creatures.

\subsection{TERROR MANAGEMENT IN THE KILLING HABIT}

The novel The Killing Habit by Mark Billingham depicts the life of a serial killer who kills the cats. The investigator Tom Throne ties up with D.I Nicola Tanner. This novel is based on a real incident ofthe Corydon Cat Killer and later the M25 cat killer, the individual far responsible for the deaths of up to four hundred pet cats, as well as a large number of squirrels, rabbits and foxes, is now simply referred to as UK Cat Killer, with offences committed as far away as Gloucestershire, the West Midlands and the Isle of Wight. It makes the reader to understand that there is a real killer killing cats in United Kingdom. Terror Management theory tells that the people who indulge in animal cruelty or abuse will have a feeling of superiority in them. Such people think them to be superior to any other living beings of the world. The same way in the novel the superior feeling of an individual results in animal abuse.

When words in chapter X are analyzed, Melita Perera, a psychiatrist says that the reason for the serial killer to kill cats in cruel way is to show his power. She says that

Whatever this individual thought he was doing, and however much pleasure he derived from doing it, his actions were about power (p.968).

This line very well explains that the killer chooses cats as his victims because he thinks them to be powerless and inferior, he assumes himself to be powerful and superior.

In the beginning of the novel in chapter I, Tom Throne tells about the murder of cats to his companion but the reaction of his friend or the reply of his friend is

They're just cats (p.210)

This depicts the superior feeling of human beings. Humans think the life of animals to be unworthy and the life of humans to be superior. Life is same for any being on this earth.

In chapter VIII, Tom throne the central character of the novel describes how the animals were killed,

The unfortunate animals like the one in the photograph. Buried in the back garden, as opposed to being laid out, head less, on a front lawn, or displayed in pieces beneath the owner's bedroom window (p.842).

This description of Tom Throne about the state of the dead animals shows how the serial killer had been very rude to those non human animals thinking him to be superior.

Animals are tortured cruelly by humans in the name of superiority and pleasure. The way the cat killer kills the cats in the novel is horrible. They are killed mercilessly. Thus the major cause for animal abuse is the feeling of superiority.

\subsection{VIOLENCE GRADUATION HYPOTHESIS}

Most of the serial killers begin with killing animals and they gradually move to human beings. According to Violence Graduation Hypothesis, Children who abuse animals may be desensitised to the abuse, and therefore move onto violence to humans in adulthood, this is termed as violence graduation hypothesis. Violence towards animals and violence towards humans is related throughout the offender's lifetime. Throughout history, those with the violent tendency towards animals had said likely to be a risk to humans. In this novel, the serial starts killing animals and he gradually moves to humans, especially women.

In chapter VI Tom Throne doubts that the killer might have even killed human beings. He says that,

I think we might be looking for several human victims already (p.675).

The investigator doubts that there might be human victims.

In chapter VIII Mark Billingham the novelists writes that,

Throne might believed that the cat killings were part of a pattern that already involved in human casualties, but there was no doubt that the slaughter of animals in this scale (p.831)

It tells clearly that the killer might be engaging in human casualties as well.

In chapter XIV of the novel there is a passage,

As the cat killings appeared to have begun around six months earlier, Throne had decided somewhat arbitrarily to go back as far as eighteen months searching for human victims with somewhere around seven hundred homicides in that period, of which approximately a third of victims had been female (p.1275).

The serial killer begins by killing animals and moves gradually to humans, and all his victims were females.

In the last chapter of the novel, that is in the chapter LXXIV the serial killer who killed cats gradually increases his murder by killing human beings, especially by killing women. There is also a common factor in which these 
women's are killed. In the chapter XVII of the novel Tom Throne investigates and comes to know that

All the victims were single, for one reason or another, and all of them were killed at home (p.1473).

Thus the serial killer started killing animals and he gradually moved to humans. With reference to Violence Graduation Hypothesis victims of the killer had increased gradually.

\subsection{DEVIANT GENERALIZATION HYPOTHESIS ANALYSED IN THE NOVEL}

Deviant Generalization hypothesis is about the deviant behaviours. It states that animal abuse is one of the many forms of anti social personality disorder that can be expected to arise from childhood. For instance, if a child hits another child then the one who gets hurt goes home and smacks the cat. Later the child turns to be a serial killer.

When the life history of the real life serial killer is taken into account, Albert Henry Desalvo, was born on September 3, 1931 and died on November 25, 1973 was a criminal in Boston, Massachusetts who confessed to being the BostonStrangler, the murderer who had killed thirteen women. When the early life of Albert is analysed it was found that his father was a violent alcoholic, who at a point knocked out all of his wife's teeth and bent her fingers back until they broke in front of children. As a result of this childhood trauma Desalvo started to torture animals. He tortured animals when he was child, he trapped dogs and cats in a box and would shoot them with arrows.

When he grew old, thirteen women between the ages 19 and 85 were murdered in Boston area. Most of the women were sexually assaulted in their apartments, and then strangled with articles of clothing. The eldest victim died of heart attack. Two others were stabbed to death, one of whom was also badly beaten. Albert had a very traumatic childhood and this ended in torturing animals mercilessly that resulted in killing of women.

\subsection{END TO SPECIESISM}

\section{CONCLUSION}

The term Speciesism was coined in 1970 by Richard D. Ryder. It is a form of discrimination based on species membership. It involves treating members of one species as morally more important than members of other species even when their interests are equivalent. Speciesism is the failure to consider interests of equal strength to an equal extent. It is a prejudice similar to sexism and racism. It plays a role in justifying cruelty. For instance, both dog and cow need their tails removed for medical reasons. Suppose someone believes that the dog and the cow have equivalent interests, but insists that the dog receive pain relief for the operation, but is fine with the cow's tail being docked without pain relief, remarking, it's just a cow. This belief is specialist because the cow is used as an excuse. By ending Speciesism intentional animal torture and cruelty can be put to an end. By educating children about humanity and avoiding Speciesism one can stop the intentional animal torture and cruelty.

One should consider that every animal's are equal,

Birds $=$ Dog $=$ Pig $=$ Horse $=$ Cat $=$ Cow

Many people choice not to hurt dog, cow, cat but choice to hurt bird, rat, pig, donkey because of selective compassion by ending. They feel only their pet can feel pain. But all animals can feel love, pain and care.

\subsection{ANIMALOGRAPHIES}

Animalographies tells about the positive relationship between humans and animals.Animalographies is the life writing by humans about animals. It tells about the human and non human melding. Animalographies speak about the space between animals and humans. It is the contraction of humans with non human species especially animals. Post humanism talks more about animalographies; it sees humans being embedded with environment, with the species in the environment.

Even in the novel The Killing Habit in chapterVIII the bond between humans and four legged innocent victim are described as,

She had made him tea and fussed over the kitten. She had bought to replace the cat she'd lost, and tears had only welled up once, she talked about the morning a few months before when she'd come out of the house and almost stepped into what had been left for her pet

Sodden scraps of blood-soaked fur and flesh

She'd picked up the kitten and pulled it to her chest.(p.822)

This passage depicts the love, the relation between the human and the animals.

Each and every human being should not consider them just as animals. This world is not only for humans, it is also for the non human animals. Every child should be taught to be affectionate with animals. Every human should be the Voice for the Voiceless. As Mark Twain said "Kindness is the language which the deaf can hear and the blind can see" (web). A conclusion section must be included and should indicate clearly the advantages, limitations, and possible applications of the paper. Although a conclusion may review the main points of the paper, do not replicate the abstract as the conclusion. A conclusion might elaborate on the importance of the work or suggest applications and extensions. 


\section{REFERENCES}

[1] Billingham P. D. Mark. The Killing Habit. Kindle Edition 2018, Sphere Little, Brown Group, Kindle.

[2] Fritz Robb. History's A Bitch: A Dog Walk Through the Time His Master's Voice. Mc SWEENY'S, 2012, Web.

[3] Siebert Charles. The Animal Cruelty Syndrome. The New York Times Magazine, 2012, Web.

[4] Gleyzer R. Animal Cruelty and Psychiatric Disorders. Pubmed, 2002

[5] Steelhammer Rick. FBI uses animal abuse data to study correlation to crimes against humans. Charleston GazzetteMail, 2016, web

[6] Blue Alexis. How fear of death affects human life towad animal life. Science Daily, April 2017, web.

[7] Herzog Hal. Animal Cruelty and the Sadism of Everyday Life. Psychology today, 2013, web.

[8] HeidarizadehNegin. The Significant Role of Trauma in Literature and Psychoanalysis. Science Direct, 2015, web.

[9] Watts Sarah. First They Tortured Animals, Then They Turned to Humans. Real Crime, January 03, 2018, web.

[10] The Graduation Hypothesis: does juvenile animal abuse lead onto adult interpersonal violence. Hartpury Student Research Journal, Febrauary 02,2018, web.

[11] Serial Killers Who Abused Animals First, Ranker Vote on everything, 2019, web.

[12] Barson Michael. The Editors of Encyclopedia Britinicca. Albert Desalvo American Criminal, feburary 2019, web. 